\title{
"Oumense het blotvoet gebruik": Nederlandse taalresten in de variëteiten van het Afrikaans*
}

\author{
Karin van Lierop, VDO Opleidings- en Adviescentrum, \\ Hogeschool van Arnhem en Nijmegen, Nederland
}

\begin{abstract}
Oumense het blotvoet gebruik": Dutch relics in the regional varieties of Afrikaans. The Bureau of the WAT has developed a survey of all varieties of Afrikaans. One part thereof is the survey of Dutch language relics in the Afrikaans regional varieties which is discussed here. From earlier surveys it has been shown that many Dutch relics are present; the Dutch language and in particular the dialect from Holland from the 16th and 17th centuries have had a strong influence on (the origin of) Afrikaans. Questionnaires were used to check with 183 informants from the Northern and the Western Cape whether Dutch relics are still present in the varieties they use, on the fonetic as well as the lexical level.

The survey has shown that Dutch relics are found on both levels. In the pronunciation especially there is still $[\phi]$ where standard Afrikaans has [e], and less often [y] is found instead of [œy]. It is noticeable that the [ai]/[i] variation is present less frequently, while in Dutch a parallel development in the diphtongisation of [y] and [i] has occurred. Afrikaans has seemingly undergone an independent development in this regard. Most phonetic relics were found in Namaqualand, particularly among informants with little schooling, and somewhat more among women than among
\end{abstract} men.

On a lexical level the results were quite different. There are still many Dutch relics present in word meaning as well as in knowledge of idioms. The Muslim community of Cape Town scores particularly high in this regard, while phonetic relics were scarcely found. Informants with higher education levels score more highly in this regard than those with lower schooling or less, and among men more lexical relics are recorded than among women.

Lastly, both on a lexical level and on a phonetic level, a number of indirect results were gathered from the survey which also point to the presence of Dutch language relics.

Keywords: WOORDEBOEK VAN DIE AFRIKAANSE TAAL, INVENTORYING OF RELICS, USE OF LANGUAGE DESCRIPTION, QUESTIONNAIRE, INFLUENCE OF DUTCH ON AFRIKAANS, PHONETIC LANGUAGE RELICS, SOUND VARIATION, LEXICAL LANGUAGE RELICS, WORD MEANING, IDIOMS, CORRELATIONS WITH SEX, SCHOOLING AND AGE, INDIRECT RESULTS

Samenvatting: Het Buro van die WAT heeft een onderzoek ontwikkeld naar alle variëteiten van het Afrikaans. Een deelproject hiervan is het hier te bespreken onderzoek naar Nederlandse taalresten in de variëteiten van het Afrikaans. Uit eerdere studies is gebleken dat er nog veel

* Een onderzoeksproject van het Bureau van die WAT in samenwerking met de Nederlandse Taalunie en het Kaaps Forum voor Neerlandistiek. 
Nederlandse taalresten aanwezig zijn; de Nederlandse taal en in het bijzonder de Holland-variant wit de 16e en 17e eeuw heeft immers een sterke invloed gehad op (het ontstaan van) het Afrikaans. Vha vragenlijsten is er bij 183 informanten uit de Noord-Kaap en de West-Kaap nagegaan of er nog Nederlandse taalresten aanwezig zijn in de variëteit die zij spreken, zowel op fonetisch als op lexical gebied.

Gebleken is uit onderzoek dat er op beide gebieden nog Nederlandse resten te vinden zijn. In de spraakklanken blijkt er vooral nog sprake te zijn van de [ø] waar standaard Afrikaans de [e] heeft en, in mindere mate, komt de [y] voor in plaats van de [œy]. Opvallend is dat de [ai]/[i]-wisseling veel minder voorkomt, terwijl er in het Nederlands een parallelle ontwikkeling is geweest in de diftongering van [y] en [i]. Kennelijk heeft het Afrikaans hier een eigen ontwikkeling ondergaan. De meeste fonetische taalresten zijn gevonden in Namaqualand, met name bij informanten met weinig opleiding en iets meer bij vrouwen dan bij mannen

Op lexicaal gebied ziet het beeld er heel anders uit. Zowel in woordbetekenis als wat betreft de kennis van idiomen blijken er nog veel Nederlandse taalresten aanwezig te zijn. Hier scoort vooral de Moslimgemeenschap in Kaapstad erg hoog, terwijl daar nauwelijks fonetische resten zijn aangetroffen. Informanten met meer schoolopleiding scoren hier hoger dan die met lagere schoolopleiding of minder en bij mannen noteren we meer lexicale resten dan bij vrouwen.

Tot slot zijn er op lexicaal en op fonetisch gebied een aantal indirecte resultaten uit het onderzoek voortgekomen die eveneens wijzen op de aanwezigheid van Nederlandse taalresten.

Trefwoorden: WOORDEBOEK VAN DIE AFRIKAANSE TAAL, INVENTARISATIE VAN RELICTEN, NUT VAN TAALBESCHRIJING, VRAGENLIJST, INVLOED VAN HET NEDERLANDS OP HET AFRIKAANS, FONETISCHE TAALRESTEN, KLANKWISSELING, LEXICALE TAALRESTEN, WOORDBETEKENIS, IDIOMEN, CORRELATIES MET GESLACHT, OPLEIDING EN LEEFTIJD, INDIRECTE RESULTATEN

\section{Inleiding}

Als het Afrikaans, zoals de opvatting heerst, geen dialecten kent, dan kent het toch zeker variëteiten, die in veel gevallen spreek- en/of streektaal gebonden zijn. Het Woordeboek van die Afrikaanse Taal (WAT) is in het verleden vaak verweten zich in zijn lexicografie uitsluitend te richten op het standaard Afrikaans en te weinig recht te doen aan regionale en sociale variëteiten. In het opnamebeleid echter van het WAT spreekt de redactie zich expliciet uit dat de lemmakeuze van het woordenboek een weerspiegeling moet zijn van de lexicale items waaruit de woordenschat van het Afrikaans bestaat en daarmee sluit het WAT materiaal in uit alle variëteiten van het Afrikaans, want "die WAT is 'n woordeboek vir Afrikaans, nie vir Standaardafrikaans nie" (Inleiding, WAT IX, 1994: i). Het WAT beschikt dan ook over een uitgebreide verzameling van streektaalmateriaal, regionaal gekleurde woorden en uitdrukkingen, en zoekt al langer naar uitbreiding van haar eigen onderzoek naar de variëteiten van het Afrikaans.

Onder auspiciën van het Kaaps Forum voor Neerlandistiek heeft het WAT een breed onderzoek ontwikkeld naar alle variëteiten van het Afrikaans. Een deelproject daarvan is het hier te bespreken onderzoek naar Nederlandse taal- 
resten in de variëteiten van het Afrikaans, een onderzoek naar overblijfselen van archaïsch taalgebruik waarvan de herkomst is terug te voeren op het $\mathrm{Ne}$ derlands of op Nederlandse dialecten die niet (meer) in het standaard Afrikaans voorkomen.

Uit materiaal van het WAT en van andere studies op dit gebied, is gebleken dat er veel Nederlandse taalresten voorkomen in de variëteiten van het Afrikaans. Vooral vanwege de geografische geisoleerdheid van de sprekers van die variëteiten zijn zekere Nederlandse resten hierin bewaard gebleven, waar ze niet (meer) in het standaard Afrikaans voorkomen. Met het hier te bespreken project hebben we ons geconcentreerd op die resten, in vijf, geografische tamelijk geisoleerde, gebieden: Namaqualand, Genadendal, Mamre, Saron en de Moslimgemeenschap in Kaapstad.

Om tot een systematische inventarisatie van deze relicten te komen, heeft het Buro van die WAT contact gezocht met de Nederlandse Taalunie in Den Haag. Onder de koepel van de Taalunie functioneert al enige jaren een overlegstructuur voor dialectlexicografie in Nederland en België, het overleg Regionale Woordenboeken, het ReWo. Twee medewerkers van het ReWo, Joep Kruijsen van de Nijmeegse Centrale voor Dialect- en Naamkunde in Nijmegen en Jacques van Keymeulen van het Seminar voor Nederlandse Taalkunde en Vlaamse Dialectologie in Gent, hebben samen met de hoofdredacteur van het WAT, Dirk van Schalkwyk, het vooronderzoek voor het project "Nederlandse taalresten in de variëteiten van het Afrikaans" in Namaqualand voorbereid en uitgevoerd. Inmiddels is het project afgerond en dit artikel biedt een inzicht in de resultaten die uit dit project zijn voortgekomen.

Nadat we hieronder kort ingaan op het nut van taalbeschrijving, geven wij een beschrijving aan van het project zelf. Daarin wordt ingegaan op het doel van het project, de fasering en de werkwijze ervan. Tevens gaan we in op de vragenlijst die we hebben gebruikt voor de enquêtes. In een volgende paragraaf bespreken we summier de invloed van het Nederlands op het Afrikaans in historisch perspectief, waarbij we ons beperken tot die aspecten die relevant zijn voor het onderhavige onderzoeksproject. Daarna bieden wij een overzicht van de resultaten en conclusies, zowel op fonetisch als op lexicaal gebied, zoals die uit het onderzoek zijn voortgekomen. We besteden hierbij tevens aandacht aan de correlatie tussen de aanwezigheid van Nederlandse taalresten enerzijds en de leeftijd, het opleidingsniveau en het geslacht van de informanten anderzijds. Bovendien vermelden we hier een aantal indirecte resultaten uit het onderzoek die wij voor ons doel noemenswaardig achten. We beëindigen dit artikel door de aandacht te vestigen op het belang van dit onderzoek voor de lexicografie.

\section{Matjieshuizen of het nut van taalbeschrijving}

Het nut van een taalbeschrijving als die van de variëteiten van het Afrikaans 
ligt niet alleen op taalkundig vlak, maar heeft ook cultuurhistorische waarde. De traditionele woordenschat verdwijnt snel en is vaak nog enkel opgeslagen in het geheugen van de oudste generatie. Het is belangrijk dit materiaal op te vragen en te registreren en daarmee een historische woordenschat die hoort bij een samenlevingsvorm die aan het verdwijnen is of al is verdwenen, vast te leggen.

Registratie van het hiergenoemde materiaal en opname ervan in het woordenboek heeft natuurlijk in de eerste plaats een taalkundig nut, omdat het een deel van de taalwerkelijkheid ontsluit. Vooral via mondelinge enquêtes is het vaak mogelijk zeer fijn onderscheiden klankvariaties te geven, zoals ook is gebleken uit het hier te bespreken project. Belangrijker nog is de lexicaalsemantische en etymologische waarde van dit soort onderzoek. Woordenboeken openen hiermee namelijk de mogelijkheid semasiologische en onomasiologische woord- en betekenisvelden te bestuderen en de verspreidingsgeschiedenis van woordvormen en van betekenissen na te gaan. Kennis van variëteiten van een taal, toegankelijk gemaakt door een systematisch geordende verzameling van het materiaal, is een belangrijk bestanddeel van taalkundige kennis in ruimere zin."

Daarnaast wordt met het beschrijven van variaties van het Afrikaans een cultuurlandschap ontsloten. Doordat een woord meestal langer blijft bestaan dan de referent, is lexicologisch onderzoek ook dienstig aan de cultuurgeschiedenis: de taal, de variatie geeft een afspiegeling van de alledaagse werkelijkheid van een bepaald deel van de bevolking in een bepaalde tijd. Men vergelijke bijvoorbeeld het woord matjieshuis waarvan de referent nagenoeg verdwenen is. Tijdens ons onderzoek hebben we in Steinkopf nog een aantal van deze matjieshuizen aangetroffen.

Het WAT zegt over matjieshuis onder andere het volgende: een matjieshuis is een "informele of tydelike woning wat bestaan uit 'n sirkelvormige raamwerk van pale wat met dwarslatte aan mekaar verbind en met matjies gedek word". Hier (in Namakwaland) het die boere die matjieshuis ontwikkel en agter die veetroppe aan "verhuis" (A. Coetzee in G.J. Labuscagne: Feesbundel, 1959, 47). Matjieshuizen kunnen makkelijk worden vervoerd, hetgeen een ideale behuizing is voor het nomadenvolk in Namaqualand, ideaal ook in het klimaat in deze streek: de matten zwellen op als het regent, waardoor ze nauwelijks water doorlaten en ze krimpen als het warm wordt, zodat de wind erdoorheen kan waaien. Nu de mensen andere vormen van bestaan hebben gevonden en niet meer trekken, zijn de matjieshuizen nagenoeg verdwenen.

Taal is niet alleen een afspiegeling van de culturele geschiedenis van een (deel van de) bevolking, maar in taal zien we ook sociale variaties; een taalVariëteit kan sociaal en situationeel gebonden zijn. In ons onderzoek blijkt dat bljvoorbeeld uit de verschillende resultaten bij informanten met een middelbare choolopleiding of zij die lagere of geen schoolopleiding hebben gehad: de etste groep.neigt er veel meer naar de standaard Afrikaanse uitspraak, de uitpraak die sociaal aanvaard is, te hanteren dan de tweede groep. 


\section{Beschrijving van het project}

\subsection{Doel}

In het onderzoek naar de taalvariaties binnen het Afrikaans spelen de talen die het Afrikaans hebben beinvloed een bijzondere rol. Aangezien het Afrikaans voor een belangrijk deel uit het Nederlands is ontstaan - de woordenschat van beide talen loopt voor een groot gedeelte parallel - is dit deelproject van eminent belang.

De bedoeling van het onderzoek is na te gaan of verschijnselen die in de dialectische, sociolectische of etnolectische variëteiten van het Afrikaans voorkomen, maar niet in het standaard Afrikaans, verklaard kunnen worden als import uit het Nederlands (en de historische dialecten daarvan) als "toeleverancier" van taalvormen, ofwel als ontwikkelingen binnen het Afrikaans zelf.

\subsection{Fasering}

Het project is opgedeeld in vier fasen.

In een eerste fase is er een verkennend vooronderzoek geweest in Namaqualand in Springbok en omgeving. Namaqualands, als een van de opvallende variëteiten van het Afrikaans, zou een goede aanduiding kunnen bieden van de mogelijke resultaten.

In fase twee is er in samenwerking met de medewerkers uit Gent en Nijmegen een vragenlijst opgesteld voor het inwinnen van materiaal.

De derde fase bestond uit het werven en voorlichten van medewerkers en uit het toetsen en invullen van de vragenlijsten. Voor dit doel zijn in eerste instantie de vijf genoemde gemeenschappen benaderd: Springbok en omgeving, Genadendal, Mamre, Saron en de Moslimgemeenschap in Kaapstad.

In de vierde fase is ten slotte het verzamelde materiaal ontleed en verwerkt. Dit materiaal zal worden ingevoerd in het normale systeem van het Buro van die WAT.

\subsection{Werkwijze}

De gegevens voor het onderzoek zijn verzameld door middel van vragenlijsten. Daartoe zijn medewerkers aangezocht die de plaatselijke variëteit kennen en tegelijk taalkundig zodanig zijn onderlegd dat ze ook bij de opvraging en de eerste verwerking behulpzaam kunnen zijn. De medewerkers hebben plaatselijke zegslieden gezocht en hen de vragenlijst voorgelegd, waarna de vragenlijsten terug zijn gestuurd naar het Buro van die WAT waar ze door schrijfster dezes zijn verwerkt. De vragenlijsten zijn steeds afgenomen door betrokken medewerkers of door Van Schalkwyk zelf.

De gebruikte vragenlijst is tot stand gekomen op basis van resultaten uit het vooronderzoek in de eerste fase en bestaat uit twee delen: een fonetisch/ 
fonologisch deel en een lexicaal deel. In het eerste deel gaat het met name om de volgende klankverschijnselen: het behoud van [y] voor [œy] (als in huus voor standaard Afrikaans huis), het behoud van [i] voor [oi] (als in Zeeuws tied voor standaard Afrikaans tyd) en het behoud van [ø] voor [e:] (als in veul voor standaard Afrikaans veel).

Het tweede gedeelte betreft vragen naar zowel de woordenschat als idiomen. Het gaat hier om variëteiten die nog wel in het Nederlands maar niet meer, of niet meer algemeen in het standaard Afrikaans voorkomen, zoals geit voor bok of nagel voor spyker.

In de vragenlijst voor de eerste enquêteronde, in Namaqualand, is een greep gedaan uit de woordenlijst die is opgesteld uit de fase van het vooronderzoek (fase 1). De vragenlijst is niet uitputtend en in die zin kan deze eerste vragenronde als experimenteel worden beschouwd. Resultaten uit dit project kunnen waardevol zijn voor eventueel volgend onderzoek en kunnen in volgende vragenlijsten worden verwerkt.

In Namaqualand zijn 54 enquêtes afgenomen bij een dwarsdoorsnee van de bevolking van Springbok en omgeving. Men kan dus ook gezien het beperkte aantal ondervraagden in deze fase spreken van een monsteronderzoek. Voor de andere gebieden betreft het in totaal 129 vragenlijsten.

Naast de vragenlijsten is er een narratief deel waarin mondelinge overlevering is geregistreerd: vrije opvraging van volksverhalen. Resultaten van dit onderdeel worden door de schrijfster dezes in eerste instantie onderzocht op narratieve en historische kwaliteiten, maar kunnen tevens een belangrijke bijdrage leveren tot de kennis van de uitdrukkingsrijkdom van variaties van het Afrikaans. De verhalen zijn niet opgenomen in het onderzoeksrapport, maar zijn beschikbaar bij het Buro van die WAT. ${ }^{2}$

\subsection{De vragenlijst}

In elk onderzoeksgebied hebben we mensen benaderd die gaan werken met de vragenlijsten. Tijdens de voorlichting aan de medewerkers hebben we hen gewezen op een aantal belangrijke zaken:

- de vragenlijst moet altijd zo worden gehanteerd dat de vragensteller de informant niet een uitspraak of antwoord in de mond legt;

- het is te verkiezen dat de informant ouder is dan 65 jaar, tenzij er jongere kandidaten zijn die de variant van de streek goed spreken; ${ }^{3}$

- het is belangrijk dat de vragensteller informanten uit de hele opnamearea vraagt;

- de vragensteller moet de antwoorden van de informanten zo nauwkeurig mogelijk beoordelen en op de vragenlijst aanduiden.

De vragenlijst heeft een A-gedeelte en een B-gedeelte. In het A-gedeelte wordt gevraagd naar bijzonderheden over de informant. Het B-gedeelte bevat de eigenlijke vragenlijst. 
Bij de vragen van het B-gedeelte zijn telkens antwoordmogelijkheden aangegeven in de lijst, daarnaast is er ruimte voor alternatieve antwoorden van de informant. Bovendien is aan de medewerker gevraagd aantekeningen te maken van opmerkelijke woorden of uitspraken tijdens de enquête.

In het A-gedeelte van de vragenlijst zijn nauwgezet de biografische gegevens van de informanten genoteerd om achteraf de taalvormen te kunnen duiden. Tevens hebben we deze gegevens gebruikt om te kunnen onderzoeken of er correlaties bestaan tussen de aanwezigheid van taalresten enerzijds en het geslacht, het opleidingsniveau en de leeftijd van de informanten anderzijds.

Opgetekend zijn:

- datum en plaats van de enquête en de naam van de medewerker;

- naam van de informant;

- geboortejaar en geboorteplaats, geslacht, plaats waar de informant is opgegroeid en de huidige verblijfplaats;

- de huistaal van de informant en de moedertaal van elk van zijn ouders;

- de taal/talen waarin de informant de schoolopleiding ontving;

- de opleiding/hoogste kwalificatie van genoten onderwijs van de informant.

Het B-gedeelte, de eigenlijke vragenlijst, is tot stand gekomen op basis van resultaten uit het vooronderzoek in de eerste fase en bestaat uit een fonetisch en een lexicaal deel.

In het eerste deel gaat het met name om klankverschijnselen; hierin wordt in de vorm van vraag- en invuloefeningen nagegaan of er in de variëteit van de informant sprake is van de volgende klankwisselingen:

- het behoud van [y] voor [œy], zoals in huus in plaats van huis, of dat de informant de [œy]-woorden misschien nog heel anders uitspreekt, b.v. een [u], zoals in hoes;

- op soortgelijke wijze onderzoeken we de [əi]/[i]-wisseling, zoals in wief in plaats van wijf;

- in een derde invuloefening onderzoeken we de $[e:] /[\varnothing]$-wisseling van woorden als besem en beusem;

- met een vierde invuloefening gaan we na of er nog sprake is van een intervocalische $[\mathrm{x}]$ in de taalvariant van de informant, zoals bij woorden als vogel tegenover voël;

- $\quad$ in een vijfde onderdeel onderzoeken we "varia" als de [ø]/[0:]-wisseling, de $[a] /[\varepsilon]$-wisseling, en de $[\varepsilon] /[a:]$-wisseling.

$\mathrm{Na}$ dit fonetisch-fonologisch gedeelte van de vragenlijst, volgen twee lexicale onderdelen:

- onderzoek naar de woordenschat/betekenis van woorden (zoals krank, rund, vaak); 
in het laatste deel gaan we na welke idiomen bekend zijn bij de informant (uitdrukkingen als die kans is verkyk of om met iets op die proppe te kom of hy is ' $n$ hele Piet).

In deze laatste onderdelen betreft het woorden en idiomen die in het standaard Afrikaans niet meer worden gebruikt, of waarvan de gebruiksfrequentie in standaard Afrikaans aan het afnemen is.

In het totaal hebben we 183 informanten bevraagd: 54 in Namaqualand, 32 in Genadendal, 30 in Mamre, 36 in Saron en 31 in de Moslimgemeenschap in Kaapstad.

\section{Invloed van het Nederlands op het Afrikaans}

In het fonetisch/fonologische onderdeel van het project hebben we het behoud van een vroeger taalstadium van het Nederlands (17e-19e eeuw) in het Afrikaans onderzocht. Dit verschijnsel is niet nieuw: Rademeyer (1938) heeft de kwestie beschreven en ook Kloeke (1950) heeft de rol van de historische dialecten in de opbouw van het Afrikaans ter sprake gebracht. Recenter onderzoek hiemaar treffen we aan bij Van Schalkwyk (1983) die zich speciaal richtte op de taal van de Rehoboth Basters en Links (1989) die de taal van de Kharkams onderzocht. Ook Ponelis (1993) besteedt in zijn studie over de ontwikkeling van het Afrikaans aandacht aan de invloed van het Nederlands op het Afrikaans.

Zowel Ponelis als Kloeke wijzen erop dat het niet de standaardtaal van Nederland is die van invloed was op de ontwikkeling van het Afrikaans. Ponelis ziet het Afrikaans als een koloniale en Hollandse variatie van het Nederlands: de Hollandse variëteit is dominant in de Nederlandse basis van het Afrikaans. Standaard Nederlands, in geschreven vorm, staat los van de spreektaalvariëteiten. Er zijn veel onderlinge verschillen tussen spreektaalvariëteiten van het Nederlands, maar ze hebben ook een aantal overeenkomsten die hen collectief onderscheiden van het Algemeen Beschaafd Nederlands en sommige komen eveneens voor in het Afrikaans. Als we die overeenkomsten in ogenschouw nemen, moeten we - aldus Ponelis - beseffen dat zowel het Afrikaans als de Nederlandse dialecten zijn veranderd sinds de vroeg moderne tijd en dat sommige overeenkomsten sindsdien zijn verdwenen uit het Afrikaans of uit sommige Nederlandse dialecten. Ponelis wijst er hier op dat de spreektaalkenmerken niet zijn overgenomen uit willekeurige, verschillende dialecten, maar dat ze waarschijnlijk allemaal een deel vormden van de 17e-eeuwse Hollandse of Amsterdamse spreektaal.

In ons onderzoek hebben we ons in eerste instantie gericht op de volgende drie klankverschijnselen:

(a) de [i]/[ai]-wisseling, als in het Zeeuwse tied voor het Nederlandse tijd en het Afrikaanse tyd;

(b) de [y]/[œy]-wisseling, als in huus voor standaard Afrikaans huis;

(c) de ronding van [e] tot [ø] als in dialectisch zeuven voor zeven. 
Vanuit het standpunt van de historische dialectologie van het Nederlands, is het verbazingwekkend dat we in het vooronderzoek wel herhaaldelijk dialectisch on-Hollands [y] in plaats van [œy] aantroffen (in woorden zoals kruus, bruun, duuwel) en zelden of nooit [i] in plaats van [ai]. In de ontwikkeling van het Nederlands lopen de diftongeringen van de oude Westgermaanse [u] (via [y]) tot de tweeklank [œy] en van de lange [i:] tot de tweeklank [əi] immers parallel en gelijktijdig.

Het voorkomen van deze tweeklanken [œy] en [əi] in het Afrikaans was juist een hoofdargument voor Kloeke om als stamland van de Afrikaanse taal het zuidelijk deel van Holland aan te wijzen. Immers, zo redeneert Kloeke, op grond van aantallen immigranten zou men evengoed een Duits of een Engels grondpatroon van de Afrikaanse klinkers hebben kunnen vinden. De parallellie van beide tweeklanken echter in de Nederlandse (Hollandse) dialecten en Afrikaans is doorslaggevend. Vergelijk:

Engels tide, Duits Zeit tegenover Nederlands tijd en Afrikaans tyd;

Engels bite, Duits beissen tegenover Nederlands bijten en Afrikaans byt;

Engels house, Duits Haus tegenover Nederlands huis en Afrikaans huis;

Engels brown, Duits braun tegenover Nederlands bruin en Afrikaans bruin.

De Nederlandse tweeklanken [œy] en [əi] komen, volgens de kaarten van Kloeke, in zo goed als hetzelfde dialectgebied voor: in de driehoek met de basis aan de taalgrens en de top in de buurt van Den Helder. De ontwikkeling is begonnen in het zuiden en is uit de "zuidtaal" door de Hollandse dialecten overgenomen in de "noordtaal" en vandaaruit tot standaard geworden.

\subsection{De [əi] $/[\mathbf{i}]$-wisseling}

Met zijn ijs-kaart geeft Kloeke een eerste houvast aan de taalgeograaf die op zoek is naar de bakermat van het Afrikaans. Het lijdt volgens Kloeke geen twijfel dat de Nederlandse dialecten, die worden gesproken in het gebied tussen de Waalse taalgrens in het zuiden en de punt van Noord-Holland in het noorden, door deze habitus verraden dat zij van alle Europese dialecten het naast verwant zijn aan het Afrikaans. Dat er sprake is van een oorspronkelijke lange [i:] blijkt uit de tegenwoordige Nederlandse schrijfwijze met het teken [əi] (bijten, rijden). De voorraad woorden met vroegere [i:] die nog in het Afrikaans leeft, is tamelijk groot en komt overeen met de voorraad gediftongeerde woorden die wij in het gebied op de kaart vinden: afgryselik, bly, blyk, ry, enzovoorts.

In het grootste deel van het vasteland van Holland moet de diftongering in de 17 e eeuw definitief haar beslag hebben gekregen, misschien eerder. Kloeke concludeert dat alle Afrikaanse woorden met gespelde $y$ (uit [i]) Hollands erfgoed zijn en dat ook de relicten uit Holland afkomstig zijn. 


\section{De $[\propto y] /[y]-w i s s e l i n g$}

Speciaal over de [œy] zijn interessante gevallen te melden in ons onderzoeksgebied. Evenals de oude [i] is ook de oude [u] zowel in het Nederlands als in het Hoogduits en Engels gediftongeerd. Maar de Nederlandse ontwikkeling wijkt van beide andere af, doordat aan de Nederlandse diftongering een tussenstadium is voorafgegaan: de [y] met umlaut, ontstaan in de tijd van de Frankische nederzetting uit en in de nabijheid van de Romaanse ontwikkeling.

Daarna komt de diftongering van de [y] tot [œy], ook eerst in het zuiden. De eerste sporen ervan kan men al vroeg in het Middelnederlands aanwijzen. In elk geval kreeg de diftongering zijn beslag nog voor het eind van de middeleeuwen in Brabant, met Antwerpen als centrum. Omstreeks 1600 begint de [œy] als voorname uitspraak in Amsterdam veld te winnen, wat des te makkelijker kon, omdat een aanloop tot diftongering ook in Holland reeds aanwezig was. In de 17e eeuw behoort de diftong [œy] tot de beschaafde uitspraak in Holland en komt zo in de standaardtaal terecht; Goeree en Overflakkee en de Zeeuwse eilanden blijven als relictgebied met [y] over. Terwijl de [y] enerzijds terrein verloor aan het Algemeen Beschaafd Nederlands, werd hij anderzijds tezelfdertijd expansief. Vanuit de lagere maritieme milieus, die in Amsterdam tot in de $18 \mathrm{e}$ eeuw de [y]-uitspraak bleven gebruiken, ging de [y] naar de Waddeneilanden, het gebied om de Zuiderzee; wellicht via Utrecht naar de Veluwe.

Kloeke heeft dit proces laten zien op zijn huis-kaart, waarop de drie achtereenvolgende gestalten van de Oudgermaanse lange [u] worden onderscheiden; het oudste [u]-stadium en het daarop volgende [y]-stadium zijn goed geconserveerd. Kloeke laat hier geografisch naast elkaar zien wat er chronologisch na elkaar is gebeurd:

(a) De oostelijke rand van het Nederlandse taalgebied (en ook de aangrenzende Nederduitse en Rijnlandse dialecten) en het Fries zijn met de uitspraak hoes op Oudgermaans standpunt blijven staan.

(b) Een reeks kleinere en twee grote huus-gebieden zijn op Middelnederlands standpunt blijven staan: West-Vlaanderen, Zeeland, Gelderland behalve de Betuwe, deels Overijssel, Drenthe, Groningen, Friesland en de Waddeneilanden.

(c) Het meest vooruitstrevende gebied met diftongering is Oost-Vlaanderen, de Brabantse provincies, half Utrecht en Zuid- en Noord-Holland.

Kloeke concludeert dat de huis-kaart, evenals de ijs-kaart, aantoont dat de naaste taalverwanten van het Afrikaans vooral te vinden zijn in het westelijke gebied. Binnen de grenzen daarvan, "en nergens anders", is volgens hem het stamland van de Afrikaanse [œy]-uitspraak te zoeken.

Ook bij de ontwikkeling van de oude [u] zijn enkele woorden in de oude toestand gefixeerd tot relicten; hier hebben we dus twee soorten: de oude [u] zelf en de geümlaute [u]. 
In het Nederlands tellen we een veertigtal [u]-relicten, waarvan ongeveer de helft mee naar Afrika is gekomen: bijvoorbeeld aspoestertjie (poesten naast mnl. puysten "blazan"), boer (etymologisch naast buur), enzovoorts. Als [y]-relict is het woord ruzie (vergelijk roes) naar Afrika gekomen. Zoals bij de [i] is de aanwezigheid van relicten een sterk bewijs voor overname.

\subsection{De parallellie doorbroken: wel [y] en geen [i]?}

Rademeyer (1938: 49) had al opgemerkt, en Kloeke valt hem in deze bij, dat bij bruin Afrikaanssprekenden de [y]-variant vaak wordt aangetroffen. Afgezien van het bekende Duusman voor Diesman "wit Afrikaanssprekende" < Duits- of Dietsman, hoort men in de taal van de Griqua's en de Rehoboth Basters wel huus, tuus, muus, enzovoorts. Kloeke (1950: 214) wijst op andere aanwijzingen waaruit blijkt dat de [y]-realisatie ook elders en niet alleen bij bruin Afrikaanssprekenden voorkomt en hij wijst de gedachte dat we hier "een oude echo van de taal der 17e-eeuwse blanken" te maken kunnen hebben, niet van de hand: "Men vergete niet, dat de taal van zuidelijk Zuid-Holland het meest heeft bijgedragen tot de vorming van het Afrikaans. Zuidelijk Zuid-Holland nu ligt niet alleen vlak tegen het ongediftongeerde gebied aan (het Zuidhollandse Goeree en Overflakkee behoort zelfs nog tot het monoftongische gebied) maar heeft de diftongering blijkbaar ook pas laat aangenomen."

Van de andere kant wijst Rademeyer; en volgens Kloeke terecht, op het bevreemdende feit dat de [i] bij de Basters niet "bewaard" is gebleven. Rademeyer (1938: 50) vraagt: "Sou die rede miskien wees dat die diftongering van [i] plaasgevind het voor die van [y], sodat die dialeksprekende immigrante van die 17e eeu onbekend was met die monoftongiese [i]?", een vraag die volgens Kloeke nog moet worden beantwoord, aangezien we overal in het Nederlands een parallellisme van [i] > [əi]- en [y] > [œy]-ontwikkeling (geografisch en historisch) kunnen constateren. De afwezigheid van [i] zou volgens Kloeke aan de taaltoestanden van de Basters kunnen worden toegeschreven, die blijkbaar "mengingen" ten gevolge hebben gehad die in Europa onbekend zijn - een intern Afrikaanse ontwikkeling dus.

Enerzijds wijst Kloeke dus voor het behoud van [y] op de nabijheid van de Zeeuwse dialecten, anderzijds voor de afwezigheid van [i] op intern-Afrikaanse ontwikkelingen.

\subsection{Ronding van [e] tot [o] als in zeuven voor zeven}

Weijnen $\left(1966^{2}: 225\right)$ en Schönfeld $\left(1970^{8}: 49-50\right)$, en Kloeke (1950: 166) met hem, beschrijven deze zeer frequente ronding in woorden als speulen, veul, beuzem voor spelen, veel, bezem in de dialecten van Holland, Utrecht en Noord-Brabant, maar ook wel in het oosten van Nederland. We hebben deze wisseling opgenomen omdat er in Zuid-Afrikaanse literatuur over variaties (vgl. Van Schalk- 
wyk 1983 en Links 1989) wordt gewezen op het bestaan ervan. Kloeke, die de vorm seuwe niet geattesteerd heeft gezien in het Afrikaans, merkt op dat deze, indien het een relictvorm in Zuid-Holland is - en dat bepleit hij op dialectologische grond - er te verwachten zou zijn. We hebben deze vorm inderdaad aangetroffen.

Verder worden in de vragenlijst nog enkele niet-standaard klankverschijnselen die in de literatuur waren gesignaleerd onder de loep genomen, zoals het voorkomen van $[\varepsilon]$ voor [a:], en het behoud van de intervocalische $[x]$ in oge, dage, ogenblik die Links (1989: 24) in Kharkam signaleert.

\section{5}

\section{Lexicale resten}

In het laatste onderdeel van de vragenlijst gaan we na welke lexicale resten van het Nederlands nog bestaan in archaïsche. variëteiten van het Afrikaans. Als bronnen hebben we voornamelijk gebruik gemaakt van Links (1989) en Botha et al. (1994).

Links gaat in zijn boek in op het metaforisch woord- en idioomgebruik van de Kharkams in Namaqualand. De meeste van de woorden, woordgroepen en uitdrukkingen die hij in een lijst weergeeft, zijn in het standaard Afrikaans onbekend en hij geeft er dan ook alle opgegeven betekenissen en connotaties bij met het oog op het achterhalen van de mogelijke etymologie. De bedoeling van deze paragraaf van onze vragenlijst is aanvullingen en geografische uitbreiding te verkrijgen op deze door Links ingeslagen weg.

Vaak zijn woorden uit de algemene taal verdwenen als de zaken waarvoor zij staan verdwijnen; als voorbeeld noemt Links snuiter en konfoor. Omdat echter vele mensen in zijn onderzoeksgebied (Namaqualand) een tamelijk geïsoleerd bestaan hebben, zijn veel "ouderwetse" zaken zoals de oude lengtematen duim (uit het Nederlands) en jaart (uit het Engels), en daarmee hun betekenaars, de woorden, hier bewaard gebleven (zie Links 1989: 69).

Enkele voorbeelden met Nederlandse lexicale restanten uit de vragendijst zijn:

blootvoet (Nederlands blootvoets), voor Afrikaans kaalvoet;

ontskiet en partikel ontskoot (Nederlands ontschieten) voor Afrikaans nie onthou nie; enzovoorts.

In het onderzoek zijn ook uit Botha et al. (1994) uitdrukkingen overgenomen, die niet standaard Afrikaans zijn en die hun oorsprong in het Nederlands vinden. Voorbeelden hiervan zijn:

die kans is verkyk (de kans is voorbij);

hy is ' $n$ hele Piet (hij is een belangrijke persoon);

om met iets op die proppe te kom (om met iets voor de dag te komen). 


\section{Resultaten en conclusies ${ }^{4}$}

Uitgaande van de theorie betreffende de invloed van het Hollands op het Afrikaans en gezien de aard van de taalresten die we hebben aangetroffen in de variëteiten van ons onderzoeksgebied, mogen we ervan uitgaan dat deze taa!verschijnselen een overblijfsel zijn uit het Hollands. Zowel de spraakklanken als de lexicale taalverschijnselen zijn naar alle waarschijnlijkheid Nederlandse taalresten, aangezien het standaard Afrikaans een eigen ontwikkeling heeft doorgemaakt waarin deze verschijnselen niet (meer) of slechts sporadisch voorkomen.

Met name door het behoud van dialectische kenmerken van het Hollands, zoals de frequente ronding van de [e:] tot [ø] en ook van lexicale en idiomatische niet-standaard Afrikaanse maar wel Nederlandse elementen, lijkt het behoud van een oorspronkelijke variatie aannemelijk.

Naast de gevraagde resultaten heeft het onderzoek een aantal gegevens opgeleverd waarnaar niet direct is gevraagd, maar die vanuit taalkundig oogpunt interessant zijn om hier op te nemen. Van een aantal van deze taalverschijnselen kan men sterk vermoeden dat hier tevens sprake is van invloed vanuit het Nederlands.

\subsection{Fonetische taalresten}

Wat betreft de fonetische taalresten hebben we ons vooral gericht op de [œy]/ [y]-, de [ai]/[i]- en de [e:]/[ø]-wisseling en de aanwezigheid van de intervocalische $[x]$. Daarnaast hebben we een aantal andere wisselingen onderzocht,

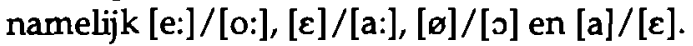

Een overzicht van de soorten fonetische resten:

$\begin{array}{lrrr}\text { [œy]/[y]-wisseling } & & 10 \% & (206) \\ \text { [e:]/[ø]-wisseling } & 18 \% & (166) \\ \text { [əi]/[i]-wisseling } & {[\mathrm{i}]} & 3 \% & (57) \\ & {[\mathrm{i}:]} & 1 \% & (11) \\ \text { intervocalische }[\mathrm{x}] & & 1 \% & (6) \\ \text { varia } & 3 \% & (26)\end{array}$

Een vergelijking van de verschillende onderzoeksgebieden op aanwezigheid van Nederlandse taalresten:

Namaqualand

Genadendal

Mamre

Saron

Moslimgemeenschap
$16 \% \quad(334)$

$3 \% \quad(31)$

$8 \% \quad(89)$

$1 \% \quad$ (7)

$1 \% \quad(10)$ 
De [e]/[ø]-wisseling is met $18 \%$ de meest voorkomende fonetische taalrest gebleken. We hebben dit klankverschijnsel onderzocht in de woorden sewe, speel, veertig, veel en besem. De klankwisseling komt het meest voor in Namaqualand (46\%). Opmerkelijk is dat Links (1989: 9) in zijn onderzoek naar de Kharkamstaal deze wisseling slechts in twee gevallen heeft aangetroffen, terwijl nu blijkt dat in de rest van Namaqualand dit klankverschijnsel (de [ø] voor de [e:]) veel frequenter voorkomt.

De [œy]/[y]-wisseling (in de woorden bruin, duim, kruis (rug), kuiken, muis, suiker, volstruis, kruis (kerk), vuis, buite, duiwel, huis) is de tweede meest frequent voorkomende fonetische taalrest: in $10 \%$ van de gevallen horen we een [y] in plaats van een [œy]. Ook wat deze spraakklank betreft, springt Namaqualand er uit: in dit gebied heeft deze wisseling met $20 \%$ de hoogste frequentie.

De [əi]/[i]-wisseling (in de woorden by, grys, konyn, vyf, kyk, gebyt, ryk, skryf, slyp, wyfie) is - in tegenstelling tot de [œy]/[y] - veel minder vaak aangetroffen: gemiddeld slechts voor 3\%; de lange [i:] komt maar voor $1 \%$ voor. Kloeke (1950: 215), Rademeyer (1938: 50) en Links (1989: 21) hebben gewezen op het feit dat de [i] veel minder bewaard is gebleven dan de [y], terwijl de [ai]/[i]-wisseling meestal samengaat met de [œy]/[y]-wisseling. Kloeke, refererend aan de taal van de Basters, schrijft dit "afwijkende gedrag der kleurlingentaal" toe aan specifiek-Afrikaanse taaltoestanden bij de Basters, maar een werkelijke verklaring voor de afwezigheid van de parallelle ontwikkeling moet volgens hem nog gevonden worden.

Het verschijnsel blijkt zich nu voor te doen in een groter gebied dan alleen bij de Basters, waarbij we overigens in gedachten moeten houden dat de Basters oorspronkelijk afkomstig zijn van Namaqualand. Bovendien, in het zuiden van de West-Kaap, bij de Moslimgemeenschap in Kaapstad, doet zich het omgekeerde voor: hier treffen we de [y]-klank slechts 1 keer aan, terwijl er 9 maal de [i]-klank is geconstateerd.

Deze resultaten geven nog steeds geen antwoord op de vraag waarom de Zuidafrikaanse ontwikkeling die bijna absolute parallellie van de oude [i] en de oude $[\mathrm{u}]$ in de Nederlandse dialecten tegenspreekt. Volgens Joep Kruijsen, die dit verschijnsel heeft besproken in een lezing in april 1998 in Nijmegen, is de combinatie niet onmogelijk. Hij haalt hierbij Weijnen (1991: 31) aan, die er in zijn bespreking van de huis-kaart van Kloeke op wijst dat het uiterste zuid-westen van Zuid-Holland, Voorne-Putten, dat tegen het overwegend [y]-realiserend Zeeuws aanligt, zich kenmerkt door een enigszins open korte [y]-klank. Kruijsen vraagt zich af of hier misschien de schakel ligt die de historische dialectkunde kan leggen tussen de bruune suuker in Steinkopf en de zuidelijkste Zuidhollandse dialecten.

Voorlopig lijken we ons echter te moeten houden aan Kloekes opvatting dat de doorbreking van de parallellie te beschouwen is als een intern Afrikaanse ontwikkeling, met dien verstande dat de [i], zij het veel minder, overigens wel voorkomt.

Het voorkomen van de intervocalische [x] is door Links (1989: 24) al geconstateerd in de taal van de Kharkams. Uit ons onderzoek (naar de woor- 
den reën, leuen, voël, spiëll, seël, oomblik) blijkt dat dit verschijnsel nog voorkomt in een breder gebied, zij het niet zeer frequent. In totaal komt de intervocalische [x] 6 maal ( $1 \%$ ) voor: 4 maal in Genadendal en 2 maal in Namaqualand.

Voor de overige spraakklanken die we hebben onderzocht, komen de [ø]/[0]-wisseling in seun ( 9 maal: $6 \%$ ) en de [œ]/[ع]-wisseling in murg (8 maal: $5 \%$ ) het meest voor; de eerste spraakklank treffen we het meest aan in Namaqualand $(11 \%)$ en de tweede het meest in Mamre (13\%). De [ø:]/[o:]-wisseling in kneukels komt in totaal 4 maal (3\%) voor, de [ $\varepsilon] /[\mathrm{a}:]$-wisseling in kerse $3 \mathrm{maal}$ $(2 \%)$ en de $[a] /[\varepsilon]$-wisseling in vars 2 maal $(1 \%)$.

Vergelijken we de verschillende onderzoeksgebieden met elkaar, dan blijkt dat in Namaqualand de meeste fonetische taalresten (334 totaal: 16\%) zijn aangetroffen. In Mamre vinden we in totaal 89 resten (8\%) en in Genadendal 31 $(3 \%)$. In Saron (7: $1 \%$ ) en in de Moslimgemeenschap (10: $1 \%$ ) treffen we nog maar sporadisch spraakklanken aan die als taalrest uit het Nederlands kunnen gelden.

\subsection{Lexicale taalresten}

Om na te gaan of er nog lexicale taalresten van het Nederlands bestaan in de variëteiten van ons onderzoeksgebied, hebben we gevraagd naar zowel de betekenis van afzonderlijke woorden als naar de betekenis van idiomen. Door de aard van de vragen hebben we vooral kunnen nagaan of de woorden en idiomen nog aanwezig zijn in de passieve woordenschat van de respondenten. Alleen bij de invuloefening waar wordt gevraagd naar de woorden blootvoet en ontskiet/ontskoot hebben we informatie gekregen over de actieve woordenschat van de respondenten.

Een totaaloverzicht van de resultaten per regio:

$\begin{array}{lll}\text { Namaqualand } & 23 \% & (252) \\ \text { Genadendal } & 31 \% & (197) \\ \text { Mamre } & 25 \%(147) \\ \text { Saron } & 15 \%(106) \\ \text { Moslimgemeenschap } & 53 \%(326)\end{array}$

Een totaaloverzicht van de resultaten uit de Woordeskat:

Wat beteken die volgende woorde?

Krank

$63 \%$ (116)

'n Rund

$13 \%$

'n Stier

$38 \%$

'n Geit

$12 \%$

'n Keuken

$3 \%$

'n Nagel

$8 \%$

Suutiies

$72 \%$

Vaak

$1 \%$ 
$\checkmark u l$ die ontbrekende woord in

Iemand wat nie sokkies en skoene aan het nie, loop ..... blootvoet

Wanneer ek iets vergeet het, het dit my ..... ontskiet/ontskoot

Een totaaloverzicht van de resultaten uit de Idiome:

Die kans is verkyk/verkeke

Om 'n gat in die hand te hê

Om baie pyle op jou boog te hê

Om met iets op die proppe te kom

$29 \% \quad(53)$

Hy is ' $n$ hele Piet

$19 \%$

Om iemand die mette te lees

$35 \%$

In die dae van Olim

$34 \%$

Om nie met iemand te kan opskiet nie

Om veel met iemand op te hê

$44 \%$

$26 \%$

Om van die reën in die drup te kom

$18 \%$

De resultaten uit het lexicografische gedeelte van het onderzoek tonen een totaal ander beeld als dat van het fonetische deel, met name wat betreft de spreiding van de aanwezige taalresten over het onderzoeksgebied.

Van de acht items uit de Woordeskat zijn de woorden suutjies (72\%) en krank $(63 \%)$ het meest bekend in alle onderzoeksgebieden. In de Moslimgemeenschap in Kaapstad zijn de informanten het meest bekend (38\%) met de woorden uit dit onderdeel, gevolgd door Genadendal (31\%). Maar ook in de andere gebieden kennen veel respondenten nog de betekenis van de woorden: in Namaqualand $26 \%$, in Mamre $23 \%$ en in Saron $17 \%$ van het aantal gevallen.

Opmerkelijk is dat in de Moslimgemeenschap, die zo hoog scoort bij de betekenis van de woorden, de actieve woordenkennis wat betreft blootvoet en ontskiet geheel ontbreekt. Deze lexicale resten treffen we nog frequent aan in Namaqualand (32\%) en iets minder in Mamre $(10 \%)$ en Genadendal (8\%). In Saron zijn deze taalresten in het geheel niet aangetroffen. Een opmerking van een informant in Saron is in dit opzicht daarom extra interessant: "Oumense het blotvoet gebruik." Over het totaal bezien scoort de actieve woordenschat (12\%) in alle gebieden lager dan de passieve woordenkennis (27\%).

Nog hoger dàn de bekendheid met de gevraagde woorden is de bekendheid op gebied van idiomen: gemiddeld 33\%. Ook hier weer springt de Moslimgemeenschap er enorm uit met $75 \%$. De respondenten in dit onderzoeksgebied geven exact de Nederlandse betekenis van de uitdrukkingen weer. Andere gebieden scoren ook hoog, maar aanzienlijk minder dan de Moslimgemeenschap: Genadendal 35\%, Mamre 29\%, Namaqualand $20 \%$ en Saron $16 \%$.

Van de items uit dit onderdeel zijn de volgende uitdrukkingen in alle onderzoeksgebieden het meest bekend: 
Die kans is verkyk

Om nie met iemand te kan opskiet nie

totaal $63 \%$

totaal $44 \%$

Het minst bekend zijn:

Om van die reën in die drup te kom

Hy is ' $n$ hele Piet

totaal $18 \%$

totaal $19 \%$

In het totaaloverzicht van alle lexicale items levert wederom de Moslimgemeenschap de hoogste score op wat betreft aanwezigheid van lexicale resten: in meer dan de helft van de gevallen $(53 \%)$ is hier bekendheid met de lexicale items geconstateerd. In Genadendal is dit ongeveer in een derde van de gevallen $(31 \%)$, voor een kwart in Mamre (25\%) en Namaqualand (23\%) en het minst in Saron (15\%).

Het is opvallend dat juist de Moslimgemeenschap zo hoog scoort hier, terwijl op fonetisch gebied hier nauwelijks Nederlandse taalresten zijn aangetroffen. Een mogelijke verklaring is dat in deze gemeenschap een negatieve connotatie wordt gegeven aan een afwijkende uitspraak, omdat de sprekers er niet van bewust zijn dat die wisseling aan een Nederlandse rest kan worden toegeschreven. Nederlands woordgebruik wordt juist positief gewaardeerd.

In Saron lopen de scores in het fonetische en lexicografische gedeelte meer gelijk: de variëteit die de mensen in Saron spreken vertoont op beide gebieden de minste Nederlandse taalresten.

\subsection{De correlatie tussen taalresten en opleiding, leeftijd en geslacht}

In deze paragraaf bespreken we de correlatie tussen de aanwezigheid van taalresten enerzijds en de genoten opleiding, leeftijd en het geslacht van de informanten anderzijds. We zijn daarbij uitgegaan van de totaalcijfers uit het onderzoek, zowel op fonetisch als op lexicografisch gebied.

Van de 183 informanten hebben 111 personen een lagere schoolopleiding of minder, onder wie 44 mannen en 67 vrouwen. In totaal hebben 71 informanten een middelbare schoolopleiding of meer genoten: 33 mannen en 38 vrouwen.

In totaal 141 respondenten zijn jonger dan 80 jaar, onder wie 66 mannen en 75 vrouwen. Veertig respondenten zijn 80 jaar of ouder: 11 mannen en 29 vrouwen.

Het totaal aantal mannen is 77 en het totaal aantal vrouwen is 106.

\subsubsection{Fonetische taalresten}

\section{- Opleiding}

Fonetische taalresten komen gemiddeld meer voor bij respondenten met een lagere schoolopleiding of minder $(10 \%)$ dan bij respondenten met een middel- 
bare schoolopleiding of meer (3\%). Bovendien komen deze taalresten gemiddeld iets meer voor bij mannen $(10 \%)$ dan bij vrouwen $(9 \%)$.

Vrouwen met een middelbare schoolopleiding scoren echter hoger (4\%) op de aanwezigheid van fonetische taalresten dan mannen uit deze categorie (1\%).

Bij de groep informanten van 80 jaar of ouder vinden we gemiddeld iets meer fonetische taalresten $(8 \%$ ) dan bij de groep die jonger is dan 80 jaar (7\%). Mannen laten in beide leeftijdscategorieën geen verschil zien: beide groepen scoren $6 \%$. Bij de vrouwen is er wel een gering verschil: bij de groep van 80 jaar of ouder hebben we iets meer fonetische resten $(8 \%)$ geconstateerd dan bij de jongere categorie (7\%).

\section{- Geslacht}

In het totaal noteren we bij de mannen 182 fonetische taalresten (6\%). Bij vrouwen ligt dit percentage iets hoger; in deze groep worden in totaal 299 fonetische taalresten geconstateerd $(8 \%)$.

De verschillen qua leeftijd zijn zo gering dat er nauwelijks conclusies aan te verbinden zijn. Wel lijkt er een correlatie te bestaan tussen leeftijd en opleiding: respondenten van 80 jaar en ouder hebben in verreweg de meeste gevallen $(87 \%)$ een lagere schoolopleiding; slechts $13 \%$ van de respondenten uit deze groep heeft een middelbare schoolopleiding genoten. Daarbij zij opgemerkt dat deze laatste categorie respondenten alleen uit vrouwen bestaat, hetgeen de correlatie tussen leeftijd en opleiding enigszins lijkt te verzwakken, aangezien bij vrouwen met middelbare schoolopleiding juist meer fonetische taalresten worden genoteerd. Of juist niet: zij zorgen ervoor dat het verschil slechts gering is. Minder fonetische taalresten bij respondenten met een middelbare schoolopleiding zou immers kunnen worden verklaard door de invloed van de leestaal.

Het totale verschil tussen mannen en vrouwen is eveneens gering: slechts $2 \%$. We mogen hier misschien constateren dat de vrouwen in het onderzoeksgebied zich iets behoudender tonen in hun taalgebruik, of dat zij in posities verkeren (minder werk buitenshuis) die hen in staat stellen deze taalresten langer te gebruiken.

Van Schalkwyk (1983: ii) heeft in zijn onderzoek naar de taal van de Rehoboth Basters een soortgelijke bevinding opgedaan: vrouwen in deze taalgemeenschap neigen er meer naar de variatie te behouden, terwijl mannen de initiators zijn van verandering in Rehoboth Afrikaans.

In sociolinguïstische studies uit West-Europa en de Verenigde Staten zien we juist vaak dat vrouwen meer de standaardvariant produceren dan mannen en algemeen wordt aangenomen dat dit taalgedrag te maken heeft met hun taak in de opvoeding en de verwachting dat een goede vaardigheid in de standaardtaal betere toekomstkansen biedt voor opgroeiende kinderen. Van Schalkwyk wijst er in zijn dissertatie dan ook op dat zijn bevindingen die van taalwetenschappers als Labov en Trudgill tegenspreken; zij beweren juist het omgekeerde, namelijk dat vrouwen vooruitstrevender zijn dan mannen waar het 
gaat om gebruik van de variëteit of de standaardtaal. Volgens onderzoek van Labov (1972: 243) zijn vrouwen gevoeliger voor de prestigevorm dan mannen en maken zij in nauwkeurig spraakgebruik minder gebruik van gestigmatiseerde vormen dan mannen. Dit zou met name gelden voor vrouwen uit de lagere middenklasse. Hij waarschuwt er echter tevens voor dat men niet mag aannemen dat het een algemeen beginsel is dat vrouwen altijd het voortouw nemen bij linguïstische veranderingen.

Volgens Van Schalkwyk (1983: 174) gelden vooral niet-talige veranderlijken als ouderdom en opleiding als factoren die de uitspraak van de Rehoboth Basters bepalen. Daartegenover leiden niet-talige veranderlijken als geslacht niet tot een beduidend verschil in de uitspraak. Aangezien het effect van het geslacht op de uitspraak bij de Rehoboth Basters heel anders is dan dat uit bij voorbeeld de bevindingen van Trudgill en Labov, concludeert Van Schalkwyk (1983: 175) dat deze correlatie kan verschillen per taalgemeenschap en dat sociolinguïsten hier voorzichtig moeten zijn met generaliseringen.

\subsubsection{Lexicon}

\section{- Opleiding}

In tegenstelling tot de fonetische taalresten, komen de lexicale resten juist meer voor bij respondenten met een middelbare schoolopleiding $(36 \%)$ dan bij die met een lagere schoolopleiding (23\%). Mannen met een middelbare schoolopleiding scoren iets hoger $(36 \%)$ dan vrouwen $(35 \%)$. Bij respondenten met een lagere schoolopleiding is het verschil groter: hier noteren we bij mannen $26 \%$ en bij vrouwen $22 \%$.

\section{- Leeftijd}

Ook qua leeftijd is het beeld op lexicaal gebied totaal anders dan op fonetisch gebied. Respondenten die jonger zijn dan 80 jaar zijn aanmerkelijk beter bekend $(30 \%)$ met het lexicon uit de vragenlijst dan respondenten van 80 jaar of ouder $(19 \%)$. Van de jongste groep scoren mannen wederom hoger (32\%) dan vrouwen $(29 \%)$. In de oudere groep is dat beeld precies omgekeerd: daar scoren de vrouwen $20 \%$ en de mannen $17 \%$.

\section{- Geslacht}

In totaal hebben we bij de mannen 466 lexicale resten geconstateerd (30\%). Bij de vrouwen noteren we relatief iets minder, namelijk 559 lexicale taalresten in totaal $(27 \%)$.

Waar we bij het fonetische gedeelte meer taalresten hebben genoteerd bij vrouwen, ligt de verhouding voor het lexicale gedeelte net omgekeerd: hier scoren mannen drie procent hoger dan vrouwen. Een mogelijke verklaring hiervoor is dat mannen procentueel meer middelbare schoolopleiding hebben genoten dan vrouwen. Immers, respondenten met een middelbare schoolopleiding scoren procentueel hoger op bekendheid met het lexicon dan respondenten met lagere schoolopleiding. 
Tevens zou hier weer een mogelijke correlatie kunnen bestaan tussen leeftijd en opleiding in de resultaten. Het is mogelijk dat hoe meer opleiding de respondenten hebben genoten, hoe meer standaard Afrikaans de uitspraak zal zijn, terwijl mensen wellicht deels vanwege hun opleiding bekend zijn met de uitdrukkingen in de idiomen, of eerder de betekenis kunnen herleiden. Een steekhoudende verklaring voor deze resultaten hebben we echter niet.

\subsection{Indirecte resultaten uit het onderzoek}

Buiten de gegevens waarnaar we hebben gevraagd in de vragenlijsten, heeft het onderzoek een aantal noemenswaardige gegevens opgeleverd zowel op gebied van de uitspraak als op gebied van het woordgebruik. De gegevens zijn verkregen uit de alternatieve antwoorden van de respondenten, die niet in de bovengenoemde resultaten tot uitdrukking komen.

\subsubsection{Fonetiek}

\section{- buitekant, buutekant, buidekant}

Vooral in Namaqualand, maar in mindere mate ook in Saron en in de Moslimgemeenschap, treffen we voor buite de variant buitekant of butekant aan. In Namaqualand komt daarnaast voor: buidekant en buudekant. De harde, stemloze [t] wordt hier vervangen door de zachte, stemhebbende [d]. Dit verschijnsel van de $[\mathrm{d}] /[\mathrm{t}]$-wisseling is al eerder opgemerkt door Links (1989: 22) in de taal van de Kharkams en door Van Schalkwyk (1983: 126) in de taal van de Rehoboth Basters. Hier gaat het echter om het omgekeerde: de stemhebbende [d] wordt in een aantal gevallen vervangen door de stemloze [ $t$ ]. De vraag is of we in onze voorbeelden niet te maken hebben met gevallen van hypercorrectie: aangezien de respondenten mogelijk weten dat ze vaak ten onrechte een [d] in een [ $t$ ] veranderen, zijn ze nu bang fouten te maken en spreken een [d] uit waar dit eigenlijk een [t] behoort te zijn. Om deze hypothese te staven is echter nader onderzoek gewenst.

\section{- ontronding van de [œy]}

Beide in Saron als in de Moslimgemeenschap treffen we ontronding van de [œy]-klank aan. In Genadendal word de [œy] in een aantal gevallen uitgesproken als [əi]: [brəin], [səikər], [dəim].

\section{- oomlik, omblik en blotvoet}

In Saron ( 3 maal) en in de Moslimgemeenschap (1 maal) treffen we bij het woord oomblik weglating van de [b] aan: oomlik. In alle gevallen zijn de respondenten vrouwelijk.

In Namaqualand doet zich nog een ander opmerkelijk taalverschijnsel voor: hier wordt in de woorden oomblik en blootvoet de lange [0:] verkort tot een [0] (beide 1 keer). Volgens Ponelis (1993: 122) kan dit verschijnsel duiden op 
een Nederlandse taalrest. Hij wijst erop dat in sommige Hollandse variaties de oorspronkelijke lange [o:] was behouden (zoals in woonsdag), terwijl deze in andere variëteiten is verkort en verhoogd tot [ $u$ ] (woensdag). In het Afrikaans was de lange [o:] verkort voordat hij was verhoogd tot een [u], zoals in blom of genog in de variëteit van Holland en in het Afrikaans.

\section{- [t]-toevoeging}

In alle regio's van ons onderzoeksgebied doet zich het verschijnsel van de $[t]$ toevoeging voor, met name in het woord reent of reunt. Zowel Links als Ponelis bespreken dit verschijnsel van de [t]-toevoeging. Links (1989: 25) noemt dit verschijnsel "epentese": "Dié verskynsel, nl. dat 'n eksplosief voor, in die middel of aan die einde van ' $n$ woord gevoeg word, is 'n prominente kenmerk voor Kharkamstaal. Hierdie verskynsel hang saam met 'n historiese neiging wat daar in Afrikaans bestaan. Reeds in Van Riebeeck se dagregister is dit bespeur. Tot vandag toe, byvoorbeeld, het hierdie epentetiese $t$ in Afrikaans behoue gebly in woorde soos geneentheid en geleentheid."

Ponelis (1993: 123) spreekt in dit geval van de "t-paragoge": toevoeging van de $[t]$ in woorden die oorspronkelijk geen [ $t$ ] kenden, zoals diakent of ervarentheid. Volgens Ponelis vormt dit verschijnsel een deel van de 17 e-eeuwse Hollandse of Amsterdamse spreektaal. Hij merkt hierbij op dat dergelijke kenmerken - die een overeenkomst vormen tussen het Afrikaans en de Nederlandse dialecten - zijn veranderd sinds de vroeg-moderne tijd en dat sommige van hen sindsdien zijn verdwenen. Zo komt de toevoeging van de [t] bij reën niet meer officieel voor in het standaard Afrikaans (slechts in tweede instantie), terwijl deze is blijven bestaan in een woord als ervarentheid. Het is dus zeer wel mogelijk dat we in het geval van reent te maken hebben met een Nederlandse taalrest uit de 17 e eeuw.

Opvallend is hier bovendien de [e:]/[ø]-wisseling in het woord reunt.

\section{- stemp/stem}

Voor het woord seël treffen we in alle gebieden het alternatief stemp(s) of stem(s) aan, de verafrikaanste uitspraak van het Engelse stamp(s). Hoewel hier duidelijk sprake is van invloed van het Engels op het lexicon, zoals Links (1989: 68) ook aangeeft bij de bespreking van de Kharkamstaal, is de uitspraak van de oorspronkelijke Engelse woorden hier verafrikaanst; de woorden zijn getransformeerd: stamps wordt [stemps] of [stems].

\section{- mug}

Een opvallend taalverschijnsel in Saron is de weglating van de [ $r$ ] in de uitspraak van het woord murg. Dit komt hier 16 maal voor, dat is de helft van de gevallen $(50 \%)$. Desgevraagd spelt een van de respondenten het woord overigens als "m u r g", terwijl in de uitspraak de [r] volledig wegvalt. 


\subsubsection{Lexicon}

\section{- geontgaan en geontskiet}

In Namaqualand treffen we de vormen geontgaan, geontskiet/geontskoot en gevergeet aan. De ge-voor het voltooid deelwoord in deze specifieke voorbeelden is niet algemeen gebruikelijk in het standaard Afrikaans en kan duiden op een Nederlandse taalrest. Volgens Links (1989: 38), die de toevoeging ge- ook heeft aangetroffen in de Kharkamstaal, komt deze toevoeging wel voor in het standaard Afrikaans, maar niet zo frequent. Dit taalverschijnsel is volgens hem te verklaren doordat men juist in het Middelnederlands deze vorm al aantrof. Er zou hier dus sprake kunnen zijn van een overblijfsel uit het Middelnederlands.

\section{- hy in plaats van sy}

Een informant uit Namaqualand gebruikt het mannelijk persoonlijk voornaamwoord hy als hij verwijst naar een vrouw, in de uitspraak: "Hy het brod geëet" (zie hier overigens ook weer de verkorting van de [o:]). Normaliter wordt in het Afrikaans sy gebruikt om een vrouwelijk zelfstandig naamwoord te vervangen. Links (1989: 78) heeft ook in de Kharkamstaal opgemerkt dat het anaforisch verband tussen het geslacht van het persoonlijk voornaamwoord en het zelfstandig naamwoord frequent wordt losgelaten en dat het mannelijk voornaamwoord vaak het vrouwelijk voornaamwoord verdringt.

Of we hier te maken hebben met een Nederlandse taalrest is onduidelijk. Wel is het zo dat in een aantal Nederlandse dialecten (bijvoorbeeld in NoordBrabant) nog steeds hij wordt gebruikt als persoonlijk voornaamwoord dat verwijst naar een vrouwelijk zelfstandig naamwoord. Deze vorm zou ook een overblijfsel uit de 17e eeuw kunnen zijn, waar er geen onderscheid werd gemaakt tussen hy en sy, tussen de mannelijke en de vrouwelijke vorm.

\section{- wedeman}

In plaats van wewenaar noteren we in Namaqualand (in Buffelsrivier) het woord wedeman. Links (1989: 60) heeft in Garies (eveneens Namaqualand) het woord weweorou gevonden. Deze variant bestaat nog in Nederlandse dialecten en zou een taalrest kunnen zijn. Mogelijk is dit ook het geval bij wedeman, maar hiervoor hebben we geen evidentie.

\section{Slot}

De grootste bate van dit soort onderzoek voor de lexicografie ligt misschien niet zozeer in het materiaal zelf als wel in het besef dat er talloze woorden, zegswijzen en idiomen bestaan, die nog steeds gehandhaafd blijven en nog niet zijn opgetekend. Deze variëteiten horen thuis in een omvattend woordenboek als het WAT, dat in zijn opnamebeleid niet zozeer gericht is op het opnemen van gespecialiseerde vaktaal maar zich veeleer wil concentreren op spreek- en streektaal. 
Het is hierom van belang dat er een breder netwerk wordt gevestigd over het hele land, om aandacht te geven aan het aanwezige materiaal. Gebleken is uit het onderzoek dat er geestdrift bestaat voor deelname aan dit soort projecten. Wellicht is dat niet verwonderlijk, het gaat immers om het optekenen van de taal die nog leeft bij de respondenten, de sprekers. De vraag is echter: voor hoe lang nog?

Taalverandering is een algemeen verschijnsel. Het proces van standaardisering van het Afrikaans, dat onder andere de verdwijning van Nederlandse taalresten uit het Afrikaans insluit, is steeds aan de gang. In sommige variëteiten van het Afrikaans, zoals uit ons onderzoek blijkt, is dit proces verder gevorderd dan bij andere variëteiten. Als deze standaardisering voortduurt, zal dit op een of ander moment voltrokken zijn.

Een vraag die na afloop van het project naar voren is gekomen: wat is de stand van Nederlandse resten in andere geïsoleerde Afrikaanse taalgemeenschappen. Alhoewel er al redelijk veel studies geschreven zijn over de taal van de Rehoboth Basters en de Griqua's, kan er nog heel wat meer onderzoek worden gedaan. Zo liggen het Richtersveld en meer afgelegen zendingsposten nog braak. Het taalgebruik van deze gemeenschappen vraagt om nader onderzoek, voordat ook deze variëtieten verder gestandaardiseerd raken en voor de wetenschap en het nageslacht verloren gaan.

Met dank aan Joep Kruijsen en Dirk van Schalkwyk

\section{Noten}

1. Joep Kruijsen heeft dit tevens besproken in zijn lezing over de start van dit project, in april 1998 in Nijmegen.

2. In tegenstelling tot de vragenlijsten is voor dit narratieve gedeelte gewerkt met opnameapparatuur. De opnames zijn in bezit van het Buro van die WAT.

3. In de veronderstelling dat juist de oudere generatie nog bekend is met Nederlandse taalresten, hebben we in de bespreking van de resultaten onderscheid gemaakt in leeftijd. De leeftijdsgrens hebben we gesteld op 80 jaar. Men vergelijke hier ook Rademeyer (1938: 49): uuuitspraken zijn onder oudere geslachten nog zo goed als algemeen, terwijl ze minder gewoon zijn onder jongeren.

4. Bij het lezen van de resultaten dient in acht genomen te worden dat niet alle onderdelen altijd volledig zijn ingevuld op de lijsten. Bovendien hebben mensen soms een geheel andere uitspraak aangegeven dan de mogelijkheden op de vragenlijst.

\section{Literatuur}

Botha, R.P., G. Kroes en C.H. Winckler. 1994. Afrikaanse idiome en ander vaste uitdrukkings. Halfweghuis: Southern Boekuitgewers.

Kloeke, G.G. 1950. Herkomst en groei van het Afrikaans. Leiden: Universitaire pers Leiden.

Labov, W. 1972. Sociolinguistic Patterns. Oxford: Basil Blackwell. 
Links, T. 1989. So praat ons Namakwalanders. Kaapstad: Tafelberg-Uitgewers. Ponelis, F. 1993. The Development of Afrikaans. Frankfurt am Main: Peter Lang. Rademeyer, J.H. 1938. Kleurling-Afrikaans. Die taal van die Griekwas en Rehoboth-Basters. Amsterdam: N.V. Swets \& Zeitlinger.

Schönfeld, M. $1970^{\circ}$. Historische grammatica van het Nederlands. Zutphen: W.J. Thieme. Stassen, A. 1975'. Zeventiende eeuwse teksten. Groningen: Tjeenk Willink. Van Schalkwyk, D.J. 1983. Fonetiese variasie in die taal van die Rehoboth-Basters. Ongepubliceerd D.Litt.-proefschrift. Johannesburg: Randse Afrikaanse Universiteit. Weijnen, A. 1966'. Nederlandse dialectkunde. Assen: Van Gorcum/Prakke. Weijnen, A. 1991. Vergelijkende klankleer van de Nederlandse dialecten. 's-Gravenhage: SDU. 